\title{
Pääkirjoitus
}

\section{Variaatiota ja tunteita}

\author{
Nika Potinkara ja Niina Hämäläinen
}

$\mathrm{V}$ uosi on jälleen lähestymässä loppuaan ja on tullut aika päästää ilmoille Eloren syysnumero. Tässä vapaateemaisessa numerossa julkaisemme yhden tutkimusartikkelin ja kolme katsausta.

Lehden tutkimusartikkeli ja yksi katsauksista kytkeytyvät folkloristiikan ja perinteentutkimuksen ydinkäsitteeseen, variaatioon. Hanna Karhun artikkeli käsittelee kirjoitetun tekstin variaation ongelmaa tarkastelemalla kirjailija, suomentaja Antti Rytkösen keräämiä rekilauluja, jotka kuuluvat Suomalaisen Kirjallisuuden Seuran arkiston kokoelmiin. Kaikki Karhun tutkimat laulutekstiversiot eroavat toisistaan, ja aineistoja on muokattu kirjoitushetkellä: muistiinpanoja kirjoittaessa tai niitä myöhemmin kopioidessa on esimerkiksi poistettu murteellisuuksia, muutettu sanamuotoja ja jätetty joitakin yksittäisiä sanoja kirjoittamatta. Karhu korostaakin, että kirjoitettuja perinneaineistoja tarkasteltaessa olisi huomioitava suullisen variaation lisäksi myös kirjoituksen variaatio.

Suullisen perinteen arkistoaineistoihin ja variaatioon liittyy myös Kati Kallion ja Eetu Mäkelän katsaus, jossa tarkastellaan historiallisen suullisen runouden sähköistä lukemista. Kirjoittajat analysoivat Suomen Kansan Vanhat Runot -kirjasarjan sähköisen version, SKVR-tietokannan, ja kehitteillä olevan Octavo-käyttöliittymän tarjoamia mahdollisuuksia. Eri kieliä ja murteita edustavan kalevalamittaisen runouden runsas ja monitasoinen variaatio tekee sähköisten hakutoimintojen käyttämisestä haastavaa, mutta teksti- ja metadata-aineistoihin keskittyvä Octavo-järjestelmä tarjoaa Kallion ja Mäkelän mukaan käyttäjälle useita etuja aiempaan verrattuna: esimerkiksi haun rajaukset on mahdollista määritellä aiempaa tarkemmin. Vaikka hakujen ulkopuolelle saattaa aina jäädä jotakin, sähköisellä luennalla voidaan muodostaa yleiskuva suurestakin aineistosta ja saada esiin sellaisia intertekstuaalisia suhteita ja samankaltaisuuksia, joita manuaalinen luenta ei välttämättä tavoittaisi.

Syysnumeroon sisältyy myös laaja, tutkijan tunteita käsittelevä katsaus. Tiina Suopajärvi, Eerika Koskinen-Koivisto, Kristiina Korjonen-Kuusipuro, Kirsi-Maria Hytönen ja Pilvi Hämeenaho pohtivat tunteiden merkitystä etnografisessa tutkimuksessa; kuten kirjoittajat toteavat, tutkijan tunteet usein "hukkuvat rivien väleihin", vaikka niiden reflektoinnin tulisi olla osa etnografista analyysia. Tunnekudelmaksi nimeämässään tekstissä kirjoittajat tarkastelevat tunteita, joita ovat kokeneet omien tutkimusprojektiensa eri vaiheissa kenttätyöstä kentältä poistumiseen ja tutkimustuloksista raportoimiseen, ja muistuttavat, että tunteilla on väliä. 
Katsaus tuo esiin myös kollegoiden keskinäisen keskustelun, reflektoinnin ja yhdessä kirjoittamisen merkitystä esimerkiksi omien tunteiden tunnistamisen välineenä.

Tämän numeron kolmas katsaus paneutuu folkloristi Aukusti (A. R.) Niemen vähemmän tunnettuun puoleen liettualaisten kansanlaulujen kerääjänä ja julkaisijana. Vilma Daugirdaitè luo katsauksen Niemen työhön, jota on pidetty tärkeänä liettualaisen folkloristiikan kehittymisen kannalta. Niemen keräämät ja julkaisemat laulut herättivät 1900-luvun alkupuolella Liettuassa huomiota, ja laulukokoelma palveli myös nationalistisia tarpeita. Neuvostoaikana Niemen keräys- ja tutkimustoiminta jäi katveeseen, mutta Liettuan uudelleen itsenäistymisen jälkeen se on taas noussut huomion kohteeksi.

Artikkelin ja katsausten lisäksi Eloressa on tuttuun tapaan konferenssiraportteja ja kirja-arvioita, ja lehteen sisältyy myös professori Pekka Hakamiehen haastattelu. Lisäksi julkaisemme vastineen viime numeroon sisältyneeseen Anna Anttilan kirja-arvioon. Antti Kivijärvi, Tuija Huuki, Harry Lunabba ja Tarja Tolonen puuttuvat vastineessaan kirja-arviossa esiin nostettuun kysymykseen mahdollisesta tiedevilpistä. Kuten vastineessa todetaan, vihjauskin tiedevilpistä on tiedeyhteisössä vakava asia. Vaikka kriittinen ote kuuluu olennaisesti tieteelliseen keskusteluun, vilpillisestä toiminnasta syyttäminen vaatii tuekseen vahvat perustelut, ja vilppiepäilyt olisi käsiteltävä ensisijaisesti tutkimusorganisaatiossa Tutkimuseettisen neuvottelukunnan ohjeiden mukaisesti. Myös Eloressa pyrimme jatkossa varmistamaan, ettei julkaisemissamme teksteissä viitata tiedevilpin mahdollisuuteen kevein perustein.

Tämän syysnumeron myötä oma pestimme Eloren päätoimittajina päättyy - ensi vuoden alussa vetovastuun ottavat Heidi Haapoja-Mäkelä Helsingin yliopistosta ja Antti Lindfors Turun yliopistosta. Molemmat ovat jo pitkään olleet mukana Eloren toimituskunnassa. Kiitämme tulevia päätoimittajia tämän haasteen vastaanottamisesta ja toivotamme onnea ja menestystä vastuulliseen tehtävään.

Lopuksi jälleen kiitokset syysnumeron kirjoittajille, vertaisarvioijille, toimitussihteerille, kielentarkistajalle ja koko toimituskunnalle! Toivotamme kaikille lukijoillemme rentouttavaa joulunaikaa ja onnellista alkavaa vuotta. 